\title{
Innovation Process Barriers in Public Sector: A Comparative Analysis in Lithuania and the European Union
}

\author{
Alvydas Raipa ${ }^{1} \&$ Vidmante Giedraityte ${ }^{2}$ \\ ${ }^{1}$ Institute of Public Administration, Faculty of Policy and Management, Mykolas Romeris University, Vilnius, \\ Lithuania \\ 2 Institute of Public Policy and Administration, Faculty of Social Sciences, Arts and Humanities, Kaunas \\ University of Technology, Kaunas, Lithuania \\ Correspondence: Vidmante Giedraityte, Institute of Public Policy and Administration, Faculty of Social Sciences, \\ Arts and Humanities, Kaunas University of Technology, A. Mickeviciaus st. 37, Kaunas, 44244, Lithuania. Tel: \\ 370-6985-7499. E-mail: vidmante.giedraityte@ktu.lt
}

Received: August 7, 2014

Accepted: August 28, 2014

Online Published: September 25, 2014

doi:10.5539/ijbm.v9n10p10

URL: http://dx.doi.org/10.5539/ijbm.v9n10p10

\begin{abstract}
Innovation design and implementation becomes one of the essential conditions for the modernization of public governance, but innovation process in public sector is a quite risky and the success is not always guaranteed, so it is important to identify and to prevent innovation barriers. Public sector organizations' abilities to identify the innovation barriers and to develop their management instruments, determine the quality and efficiency of innovation processes. The most frequently mentioned barriers to public sector innovations are a lack of founding and human resources, regulatory requirements, a lack of management support and incentives for staff, an uncertain acceptance by users, a risk-averse culture and a staff resistance. The article focuses on the classification of public sector innovation problems and barriers. The authors, using meta-analysis method, attempt to model interferences of internal and external barriers to innovation. By a content analysis of secondary data, authors try to find differences, similarities and to compare innovation barriers in Lithuania and other countries of the European Union.
\end{abstract}

Keywords: innovation, innovation process barriers, new public governance, public sector

\section{Introduction}

The catalysts of essential public management changes today become globalization values, which cover a wide range of public, state social, economic, and cultural fields. The aim of public governance is to adapt to global requirements, organizational change processes, and significantly increased public demand, requiring more responsible, more effective and more democratic public governance and new governance standards (Perry \& Buckwalter, 2010). Therefore, control systems and subsystems are included in a transformational space of public sector. In order to change traditional public governance stereotypes and value systems, to activate an interaction between governance institutions and users during a formation of foundation of new (good) public governance, it is necessary to modernize the governance. In today's modern society, the bases of public sector governance modernization become innovative policy mechanisms and a development of innovative ideas.

Global processes, social, economic and political changes, diffusion of information technology in the twenty-first century require: to reform a public administration; to modernize management practices and capacities of public servants; to mobilize all forms of resources; to improve an individual and organizational responsibility (Segarra-Blasco et al., 2008). Therefore, increasingly emphasizes the importance of public sector innovation. Innovation design and implementation become one of the essential conditions for a modernization of public governance.

According to the general innovation results, public sector in Europe innovates, but it faces a number of challenges (EPSIS, 2013). Innovation processes in a public sector are more complex than in a private. Innovations usually affect not only habits of public servants or a nature of work, but also have a huge impact on society, because they often affect essential public services. Therefore, public sector innovations get an extremely high attention and criticism by politicians, public and media. Innovation process in public sector is quite risky 
and success is not always guaranteed, so it is important to identify and to prevent innovation barriers (Bland et al., 2010). The most frequently mentioned barriers to public sector innovations are a lack of founding and human resources, regulatory requirements, a lack of management support and incentives for staff, an uncertain acceptance by users, a risk-averse culture or a staff resistance. However, a different historical, political, and economic context of countries may lead to a different importance of separate innovation barriers and to a different level of public sector innovativeness.

The barriers often not just disturb, but even stop innovation process. Therefore, public sector organizations must have abilities to identify innovation process barriers and to develop their management instruments. Public sector in Lithuania, according to Innobarometer 2010 (2011) results, is less innovative than in most EU countries. This could be caused by the dominance of certain innovation barriers. The comparative analysis may help better to understand the main problems that faces Lithuanian public sector while implementing innovation process and also to find best solutions overcoming innovation barriers.

The object of the article: innovation process barriers in modern public sector. The aim is to compare innovation process barriers. The tasks:

1) To classify innovation problems and barriers in public sector.

2) To compare innovation barriers in Lithuania and other countries of the European Union.

Research Methodology. This survey was prepared by using meta-analysis of scientific literature, interpretative method and content - analysis of secondary data. Meta - analysis of scientific literature and interpretive method were applied in order to define innovation barriers and their classification and to distinguish the main aspects of innovation risk management. Books and articles were selected which analyze public sector innovation and innovation process barriers (10 years period). Content - analysis of secondary data was used in order to indentify and compare the innovation barriers in Lithuania and European Union.

\section{The Classification of Innovation Barriers in a Public Sector}

Innovative processes affect a trend in existing operating procedures, government structures, professional models, and types of work, a scope of powers and relationships of certain professional groups. Therefore, most barriers to public sector innovation are emerging in a context of political, economical, organizational and social behaviour. Public sector risk and performance consequences are linked to vital interests of society and individuals. According to Kamensky (2011), innovation problems are the part of policy and performance management problems. Glor (2003) consider that: 'with considerable pitfalls to face, some would say it is a miracle that innovators ever take action and it is the nature of public sector management. While some innovators successfully ignore the pitfalls, these hazards are worth thinking about and innovators should consider how to deal with them' (p. 13).

Innovation barriers many theorists examine at a broad context of innovation of public governance. Organizations' innovative activities of they understand in a strategic perspective for seeking organizational operational efficiency, quality, modernizing objectives and improving reformation of organizational structures. Innovation barriers are associated with a lack of administrative creativity, improperly selected models of governance reinvention and systemic reforms, in results-oriented behavioural indicators and inability to adapt well-proven public sector innovation best practice and organizational policy (Nelson \& Svara, 2012).

Borins (2006) the barriers in public sector classifies into three groups: first, political barriers, arising in political environment, second, internal barriers, arising within the organization, and third, external barriers - the obstacles caused by external environment. Mulgan and Albury (2003) as public sector innovation barriers identify delivery pressures and administrative burdens, short - term budgets and planning horizons, poor rewards and incentives to innovate, culture of risk aversion, poor skills in risk or change management and reluctance to close down failing programmes or organisations. According to Glor (2003), innovative process management barriers are linked with some aspects of innovative thinking. Innovation interferences often are the result of thinking, study logic, a quality of assumptions and causal analysis, the identification of possible alternatives and testing and implementation errors. Glor (2003) describes innovation dilemmas that stand in each stage of innovations process and that make it hard to think about innovation. Innovator's dilemmas are: culture, challenge and motivation dilemmas. These dilemmas make clear that public sector innovation process is a complex of activities, which require careful judgments and essential thought. Therefore, innovative thinking is essential for public sector transformation, when innovation - oriented activities combine not only mechanical performance management tools and change mechanisms, but also integrate dimensions of psychological - organizational behavioural changes (Behn, 2002).

European Public innovation scoreboard (2013) emphases that barriers to innovation are as important as drivers and highlights internal and internal innovation barriers: 
- The internal barriers: a lack of sufficient human or financial resource, a lack of management support, a lack of incentives for staff, a staff resistance and a risk adverse culture.

- $\quad$ The external barriers: regulatory requirements and an uncertain acceptance by users of services.

Sufficient human or financial resource. Innovative projects need financial resources. Inflexible funding in public governance, even with a program - funding, is a major problem, caused by the alignment of centralization and decentralization principles and the characteristics of power levels and types (Page, 2005). 'Traditionally, the public sector has funded innovation by using budgetary slack or cost savings due to enhanced efficiency. The difficulty with these sources of funding is that they are uncertain' (Borins, 2006, p. 30). Borins (2006) proposes to reform financial management of public sector strengthening an internal finance for innovation, for example, by creating founds.

Management support. Organisational leadership create a climate in which people operate and interact. Top management commitment is one of the most important factors in successful innovation. Leaders must find mechanisms that demonstrate and reinforce a sense of management involvement, commitment, enthusiasm and support. Leadership can influence the perceptions of work environment that is needed for change (Isaksen \& Tidd, 2006). One of the possible barriers of public sector innovation processes is a frequent change of institutions' heads (exchange of political forces or the end of the term of office). In scientific literature it is called as 'too many hats' syndrome. Frequent changes of the heads do not allow realizing started innovative projects and making sure that changes and innovations have an impact (Hamson, 2004).

Incentives for staff and staff resistance. Public sector staff may be scared of possible consequences and are not inclined to act innovatively. Hamson (2004) participant attitude to innovations calls: 'NIMBY! Not In My Back Yard!' This attitude he describes following: 'Change or innovate if you must but please, not in my back yard or not on my watch or in my work!' (Hamson, 2004, p. 6). Resistance to innovation (contarperneurship) is conditioned by economic and psychological motivations and the lack of motivators (Perry \& Buckwalter, 2010). According to Robbins (2006), there are three types of resistance: open (staff reacts immediately, expresses the grievances), hidden (loss of loyalty and willingness to work) and delayed (real reaction becomes apparent after a certain period). Hidden and delayed resistances are hard recognized, so it is difficult to manage them. Staff resistance in innovation could be overcome by communication, involvement into decision - making, support (advice, psychological support, training in new skills), promotion, and creating of a learning organization (Robbins, 2006).

Risk adverse culture in organization. The most important obligation for public governance is to create standards of services, to maintain a continuity of decisions, regularly inform society and account for the activities. Public sector organizations, unlike private companies, cannot simply write off failures. Therefore, a system of public governance often responds to changes in conservative (safe) way (Raipa \& Giedraityte, 2012). 'The bias toward playing safe has it sharpest impact in encouraging the selection of the alternative that consists of doing nothing...' (Tan, 2004, p. 7). This usually depends on an organizational culture, which prevail in public sector organizations. Organisational culture 'is the cement that holds an organisation together' (Isaksen \& Tidd, 2006). According to Isaksen and Tidd (2006), there are three sources that form organizational culture:

1) Believes, values and assumptions of a founder.

2) Learning experiences of members as the organisation evolves and grows.

3) New believes, values and assumptions brought into organisation from new members and leaders.

Organizational culture and organizational behaviour can significantly affect innovative change management, or conversely, can stop the formation of innovative environment and become the barriers of innovative ideology development. In organizational theory it is identified as a social - psychological phenomenon of diversity of individual behaviour. A variety of behaviour is quite complicated concept and problematic phenomenon in the context of organization activities, because it is an objective factor as well as individual behaviour, its evaluation, or as an assessment of individual's competence, motivation and loyalty (Walker et al., 2010).

Regulatory requirements. Public organizations in many European countries (especially in Eastern and Central Europe) have bureaucratic structure. Bureaucracy involves a clear-cut division of integrated activities which are regarded as duties inherent in the office. A system of differentiated controls and sanctions is stated in regulations. Activities in such organizations are governed by general, abstract, and clearly defined rules which preclude a necessity for an issuance of specific instructions for each specific case (Merton, 1992). Meanwhile, successful innovation processes, according to Mulgal and Albury (2003), require 'breaking the rules'. Many public organizations are faced with regulatory requirements and unnecessary bureaucratic procedures (called red tape) 
which disturb, or even stop innovations. More rules do not necessarily ensure a better control and they can never take a place of a common sense, competence and character. To limit a red tape it is necessary to review and modify existing rules. Administrative rules must be clear, proportionate and linked to objectives (CCAF, 2010).

Uncertain acceptance by users of services. As was mentioned above, public sector innovations have an impact on society, because they affect the essential public services. Therefore, public sector innovations get high public attention. Public doubts about effectiveness of programmes, opposition and scepticism are mentioned as external public innovation barriers (Mulgal \& Albury, 2003). Citizens' acceptance of public sector innovations in scientific literature is associated with satisfaction of public services and trust in governance. Citizens' trust is a reflection of legitimacy that citizens confer on a bureaucratic system in response to innovative changes and reforms that try to make better use of public money (Vigoda - Gadot et al., 2008). The doctrine of New Public Governance is viewing citizens as active clients and coo creators whose inclusion in innovation process could increase a trust in governance, improve acceptance and help to find possible mistakes.

In environment of public sector governance there are always factors which are associated with a certain risk in implementing organization's strategic direction and dealing with functional activities or problems of organizational optimization. Therefore, an identification of risk, allows organizations to focus on their efforts in predicting potential performance barriers by providing for their avoidance and neutralization forms. Theorists usually distinguish three forms of risk management: risk identification, analysis, assessment and amortization. Such excretion of strategic risk management directions allows to predict and to avoid the barriers of innovative environment formation, innovative ideology development and innovation practice. The perception of potential risk enables organizations realistically to assess the organization's goals, values, potential, and its ability to overcome doubts, indecision and fear. In risk management, the key elements of overcoming barriers to innovation activities are a training level of executives and managers and optimal use of existing and an potential creativity (see Figure 1) (Akintoye \& Beck, 2009).

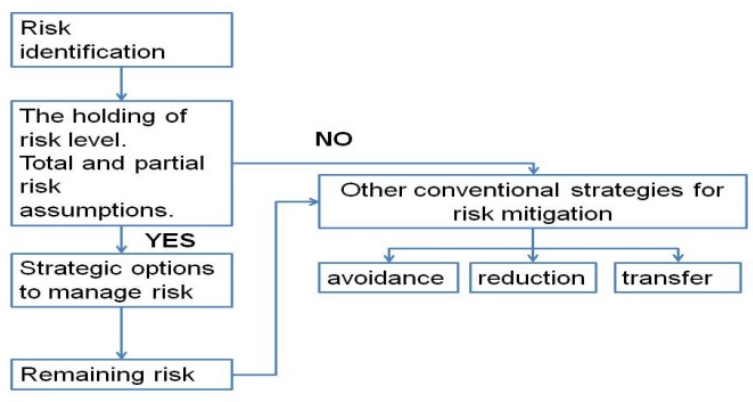

Figure 1. Risk management

Source: Akintoye \& Beck, 2009.

In order to identify innovation barriers, risk factors and to operate efficiency of public organizations, the doctrine of new public governance focuses on a number of public marketing opportunities. In public sector, marketing is not seen just as a promotional tool for commercialization, which is directed to improve sales of goods and services. Public sector organization's marketing projection is understood as a tool to evaluate a performance of strategic alternatives. Marketing here is modernized instrument between service consumers and service providers, between a formation of innovative ideology ground and innovative practice needs, between public service quantitative and qualitative parameters (Bovaird \& Loffer, 2009). Bovaird and Loffer (2009) present the mixed public sector marketing model, which is a set of environment, factors and objectives (see Figure 2). 


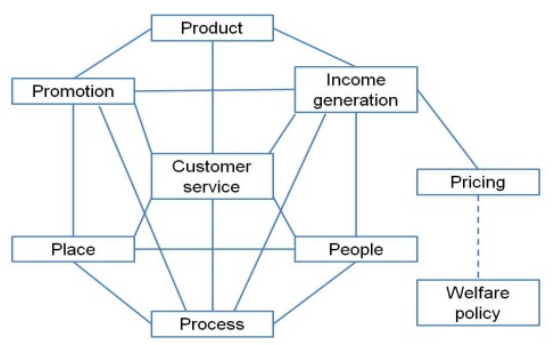

Figure 2. The expanded model of marketing for public services

Source: Bovaird \& Loffer, 2009.

One of the reasons for innovation development is a rapid rate of cross-sectoral integration and domination of networking forms in operative management. However, public sector managers and staff are trying "mechanically" to implant innovation management ideology and policy mechanisms from private sector. They usually forget, that the doctrine of new public governance a cross-sectoral integration treats not as a structural expression of fusion of three sectors, but highlights a public sector role in a development of cross-sectoral objectives, networking role in dealing with national strategic goals, coordinating of state funding programs and projects, preparation of regulatory standards and insurance of social responsibility in public sector, business and non-governmental organizations (Moore \& Hartley, 2008). As the biggest barriers of effective innovation and innovation process management, theorists usually name fundamental organizational problems. In modern public governance distinguish inter-organizational communication barriers, as a lack of development of alternatives, an unsatisfactory level of identification and coordination of problems. Often organizations' heads fall into difficult situations by forming 'their own', 'good governance' and 'good organization' criterion and not ensure appropriate inter-organizational integration, management control, objective evaluation or management entrepreneurship (Kettl \& Fesler, 2009).

\section{Data Sources}

The empirical survey is based on content-analysis of secondary data. This method is used in order to indentify and compare innovation barriers in Lithuania and European Union. The empirical part of the article is produced by the data of the European Commission's Innobarometer 2010 and European Public Sector Innovation Scoreboard (2013) (EPSIS). The objective of Innobaromer (2010) was to study the innovation strategies of the European public administration. The report gives information on various and amount of innovation, benefits of innovation with positive negative impacts, innovation strategies drivers, implementation problems and etc. This survey includes 27 European Union countries plus Norway and Switzerland. It is limited to organisations active in public administration and obtained 3699 responses (Innobarometer 2010, 2011).

Innovation Scoreboard (2013) is a pilot exercise which was launched by the European Commission following the Europe 2020 Innovation Union flagship. The pilot EPSIS survey distinguishes innovation dimensions ranging from human resources to drivers and barriers to innovation. The seven dimensions encompass 22 indicators, with data from sources including Eurostat, Organisation for Economic Co-operation and Development (OECD), World Bank, World Economic Forum and Innobarometer 2010, 2011 surveys (EPSIS, 2013).

\section{The Analysis of Innovation Barriers in Lithuania and Other Countries of the European Union}

European Public Sector Innovation Scoreboard 2013 (2013) public sector innovation barriers classifies into internal and external barriers (EPSIS, 2013). According the results (EPSIS, 2013; Innobarometer 2010, 2011) the average of internal barriers as high importance in EU countries is in $27.8 \%$ and in $26.35 \%$ in external barriers. A lack of human and financial resources in many EU countries is seen as high importance innovation barrier, meanwhile the percentage of high importance of risk-averse culture as barrier in most countries is the lowest (see Figure 3). 


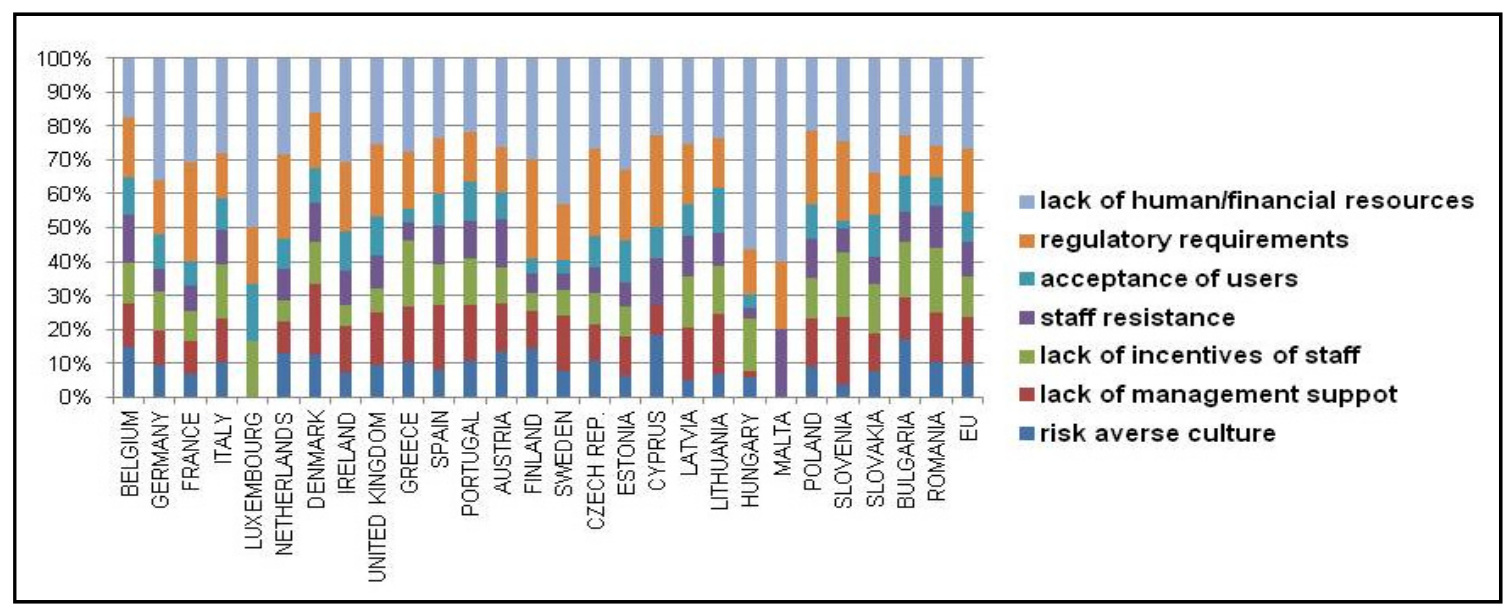

Figure 3. The high importance of barriers to public sector innovation (\%)

Sources: EPSIS, 2013; Innobarometer 2010, 2011.

Lack of sufficient human or financial resources. The most appreciable barrier to public sector innovation in many EU countries was a lack of human and financial resources. All public sector organizations in all EU countries noted this barrier as high and medium important (in 50.7\% and 26.7\%). In Lithuania a lack of human or financial resources as 'high importance' barrier was in $64 \%$, while in EU average was in $50.7 \%$ (see Figure 4). The highest percentage of this barrier as high important was in Poland (75.6\%), Estonia $(71.2 \%)$ and Bulgaria (69.1\%), the lowest percentage - in Malta (30\%), Luxembourg (30\%), Austria (33\%) and Sweden (33.7\%) (Innobarometer 2010, 2011).

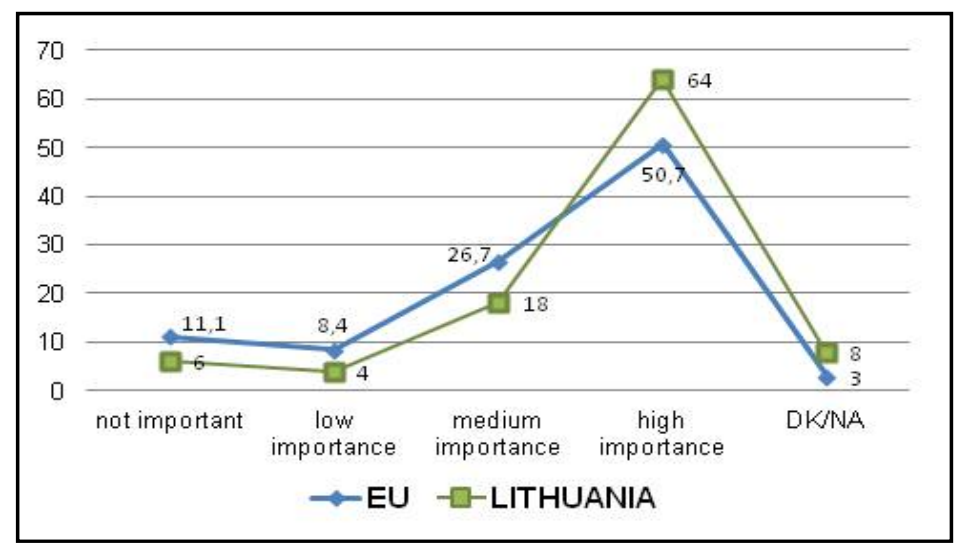

Figure 4. High importance of lack of sufficient human or financial resources as a barrier to innovation (\%)

Sources: Innobarometer 2010, 2011.

Lack of management support. According the results of Innobarometer 2010 (2011) a lack of management support Lithuanian public sector organizations mentioned as a high importance barrier (in 48\%). It is seen a significant difference in comparison with other EU countries, where average of high importance of this barrier is just in $25.9 \%$ (see Figure 5). A similar level of lack of management support as a high importance barrier is fixed in Poland (51.8\%), Belgium (48\%) and Slovenia (48\%). In Malta and Luxembourg this barrier is not mentioned as high importance (0\%), in Hungary it is only in 2\% (Innobarometer, 2010, 2011).

The following results in Lithuania may be determined by the domination of one type of organizational structure. The analysis of municipalities' administrative structures (2010) shows that in Lithuanian public sector organizations (central and local level) dominate a line organisation structure. The basic principles of the line organizational structure are minimal number of management levels and explicit subordination. A line manager has a competence to make decisions and to take actions without coordination with other managers. He/she is responsible for all functional areas of his organisation or subunit (Savivaldybiu administraciniu stukturu analize. 
Studija, 2010). A prevalence of autocracy, subordination principles and personal high - manager responsibility, leads to an importance of a leader attitude and role in innovation process.

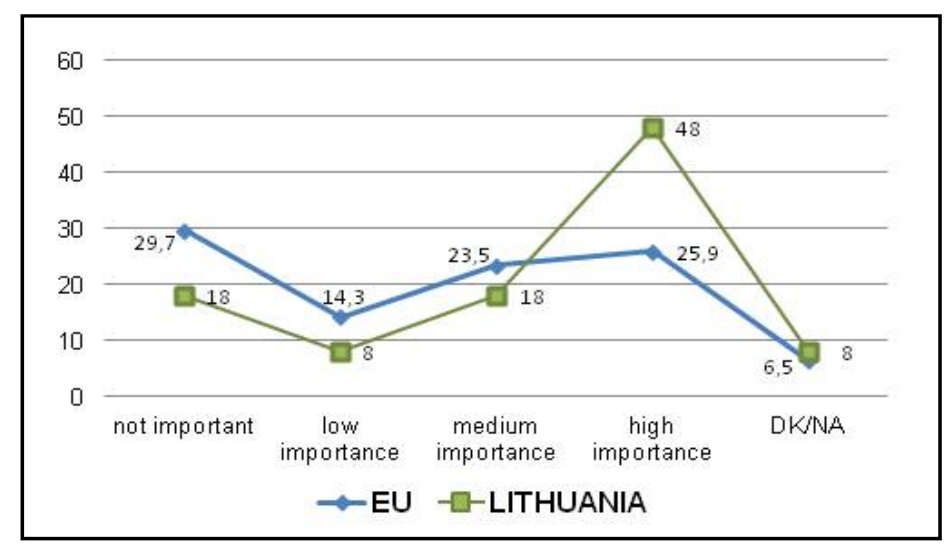

Figure 5. High importance of lack of management support as a barrier to innovation (\%)

Sources: Innobarometer 2010, 2011.

Lack of incentives for staff and staff resistance. The importance of a lack of incentives for staff as innovation barrier in EU countries is in $22.9 \%$, meanwhile in Lithuania this barrier is almost twice important - in $39.6 \%$ (see Figure 6). In Bulgaria this barrier high importance is in 50\%, Greece - 48\%, Slovenia 44\%. The lowest importance is in Cyprus and Malta (in $0 \%$ ), Sweden (5.9\%), Finland (7.9\%) and Netherlands (8\%). In many other countries, a high importance is between $8 \%$ and $26 \%$. According researches on public sector motivation in Lithuania, the most motivated factors in Lithuanian public sector are appropriate example of leader, clear formulation of tasks, involvement in a decision-making, higher degree of performance autonomy, feedback, transparent activity assessment, salary linking to work results, good climate in organisation (Palidauskaite, 2008). Factors that affect as de-motivators in Lithuanian public sector are inadequate salary, too high bureaucracy, constantly changing legislation, permanent pressure and stress at work, negative public opinion, unqualified management and ect. (Palidauskaite \& Segaloviciene, 2008).

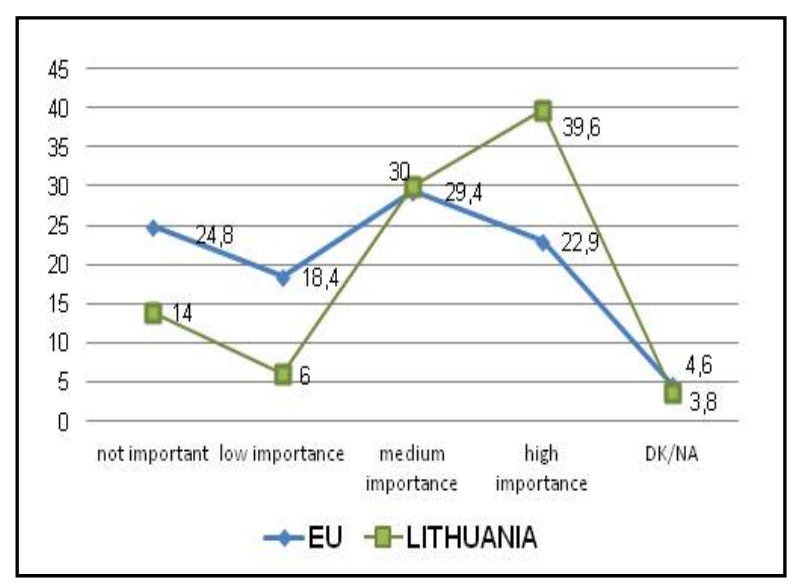

Figure 6. High importance of lack of incentives for staff as a barrier to innovation (\%)

Sources: Innobarometer 2010, 2011.

Listed de-motivators also could be the reasons for staff resistance in performance of public sector activities. Staff resistance in scientific literature is mentioned as one of mostly arising barriers in innovation process. According Innobarometer 2010 (2011), high importance of staff resistance as innovation barrier in EU countries is in 18.6\%, medium importance - in $27.7 \%$. According to this indicator, Lithuanian data is not significantly different from 
EU average. High importance of stuff resistance is in $26 \%$ and medium importance in $28 \%$ (see Figure 7 ) (Innobarometer 2010, 2011).

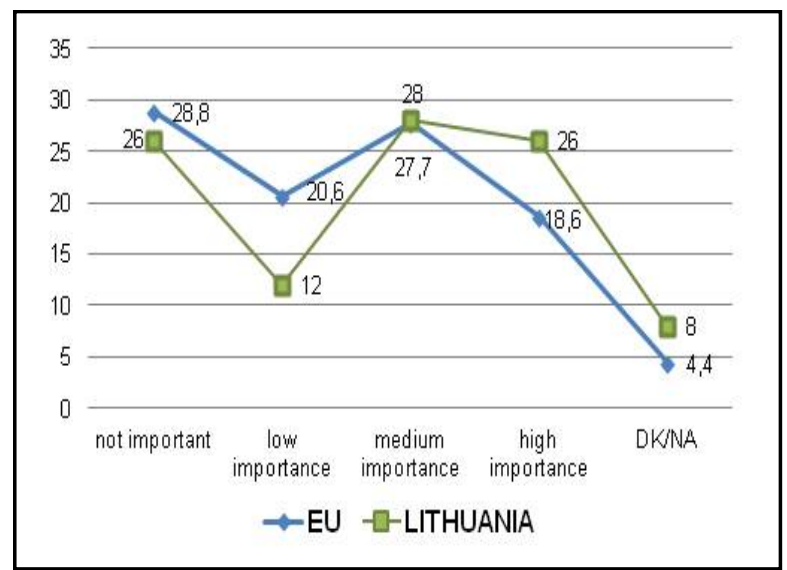

Figure 7. High importance of staff resistance as a barrier to innovation (\%)

Sources: Innobarometer 2010, 2011.

Risk-averse culture. Risk - averse culture as a barrier to public sector innovation in Lithuanian organisations was mentioned as medium important (46\%), while in EU it was in 33\%. As high important barrier it was mentioned just in $18 \%$ in Lithuania, and $18.3 \%$ in EU counties (see Figure 8). Just in a few countries risk - averse culture was mentioned as the high importance barrier: Belgium (52\%), Bulgaria (51.9\%), Cyprus (40\%) (Innobarometer 2010, 2011).

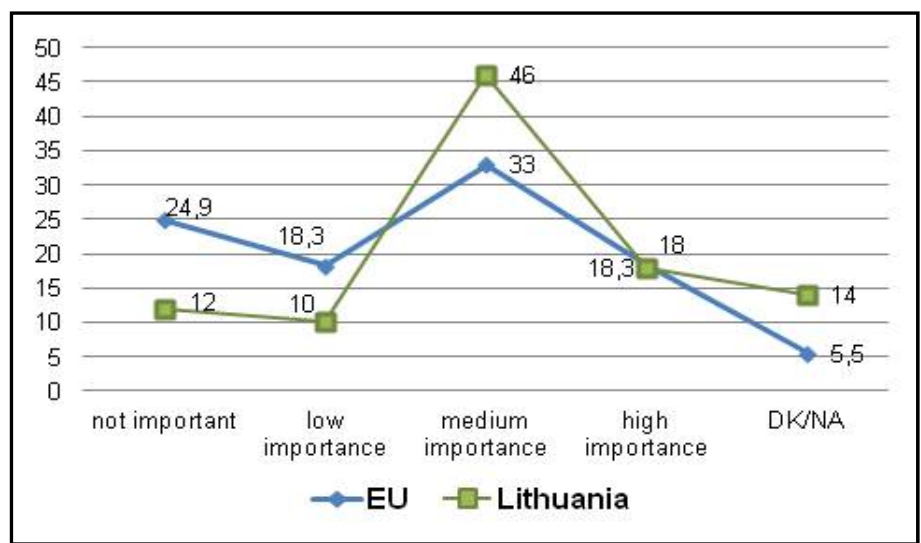

Figure 8. High importance of risk - averse culture as a barrier to innovation (\%)

Sources: Innobarometer 2010, 2011.

Regulatory requirements. Rigid regulatory in $78 \%$ was mentioned as medium and high important innovation barrier in Lithuanian public sector organizations, in EU it was $63.31 \%$. In Lithuania regulatory requirements as high importance barrier was in 40\%, in EU countries it was just in 35.3\% (see Figure 9). In some countries this barrier was mentioned as one of the most important barriers in public sector innovations, for example, in Poland it is $78 \%$, Belgium - 63\%; Cyprus - 60\%. The closest results to Lithuania was in France (41.4\%), United Kingdom (41.8\%), Greece (42\%), Latvia (45.3\%) and Estonia (46.2\%) (Innobarometer 2010, 2011). 


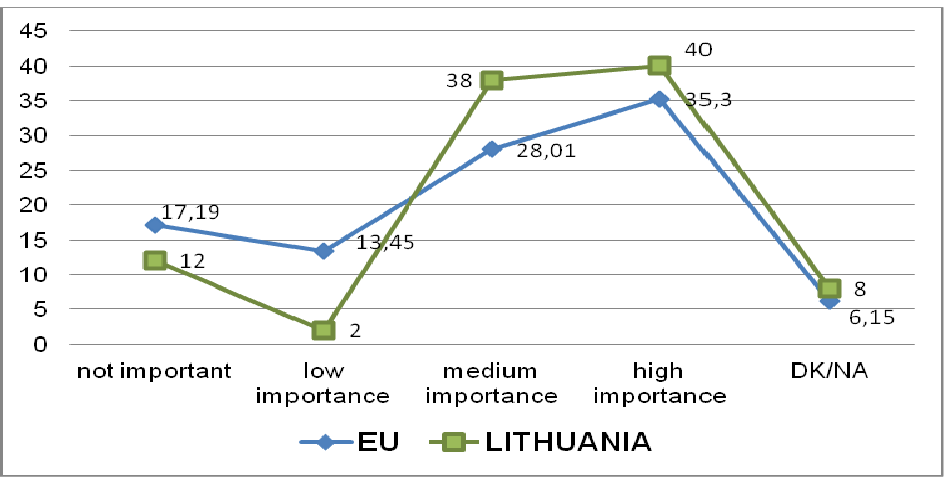

Figure 9. High importance of regulatory requirements as a barrier to innovation (\%)

Sources: Innobarometer 2010, 2011.

Uncertain acceptance by the users of services. Public sector literature recently emphasizes growing importance of participation of citizens as users of new or improved public services. In Lithuanian public sector organisations uncertain acceptance by users of services was mentioned as medium importance barrier $(32 \%)$ and high importance barrier (36\%) (see Figure 10). In EU countries medium importance of this barrier is similar to Lithuanian results (31.6\%), meanwhile high importance is just in $17.7 \%$. These results are determined by some countries, in which uncertain acceptance by users is seen as not important barrier to innovations, for example, Hungary (54\%), Luxembourg (50\%), France (46.4\%), Malta (40\%), Czech Republic (39\%) (Innobarometer 2010, 2011).

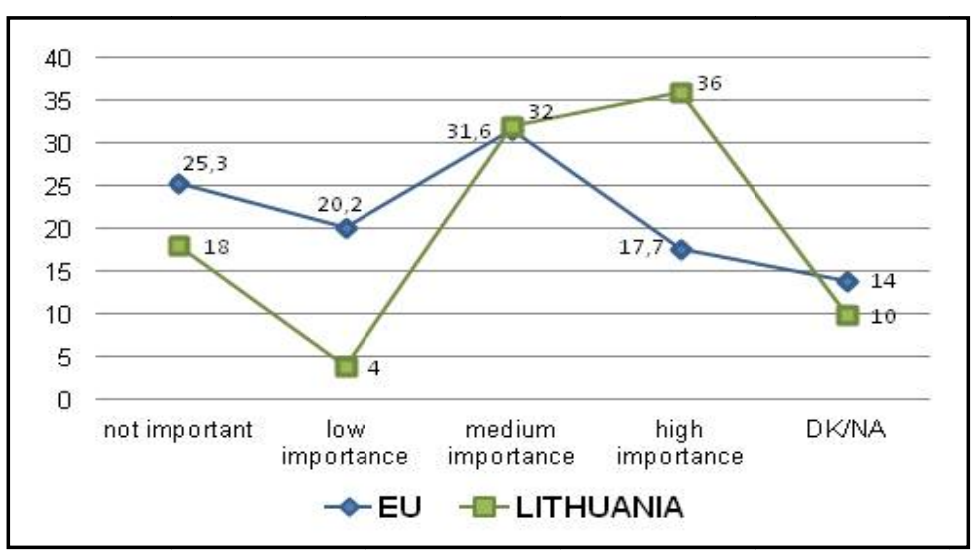

Figure 10. High importance of uncertain acceptance by the users of services as a barrier to innovation (\%)

Sources: Innobarometer 2010, 2011.

\section{Conclusions}

Most barriers to public sector innovation implementation are emerging in a context of political, economical, organizational and social behaviour. Innovation barriers are associated with a lack of administrative creativity, improperly selected models of governance reinvention and systemic reforms and inability to adapt a well-proven public sector innovation best practice and organizational policy. Usually identified internal and external barriers are a lack of founding and human resources, regulatory requirements, a lack of management support and incentives for staff, an uncertain acceptance by users, a risk-averse culture or a staff resistance. The article focuses on the classification of public sector innovation problems and barriers.

In environment of public sector innovation processes there are always some factors associated with a risk. The identification of risk, allows organizations to focus on their efforts in predicting the potential performance barriers by providing for their avoidance and neutralization forms. Risk management distinguishes such forms as a risk identification, analysis, assessment and amortization. It can help to avoid the barriers of innovative environment formation, innovative ideology development and innovation practice, to assess the organization's 
goals and values. In risk management, the key elements of overcoming barriers to innovation activities are a training level of managers and an optimal use of creativity and flexibility.

According to comparative overview of innovation barriers, the most important barrier of public sector innovation in Lithuanian and other countries of EU is a lack of sufficient human or financial resources. Meanwhile the opinions on importance of other barriers are slightly different. As high importance innovation barriers in Lithuanian public sector organizations were mentioned regulatory requirements, a lack of management support and uncertain acceptance by users of services. In many other EU countries these barriers were mentioned as low important or not important. These results could be explained by the fact, that Lithuanian public sector organizations still have a bureaucratic structure and innovative approach in public governance is just in a beginning stage.

\section{References}

Akintoye, A., \& Beck, M. (2009). Policy, Management and Finance of Public-Private Partnerships. Oxford: Wiley-Blackwell.

Behn, R. (2002). Psychological Barriers to Performance Management. Public Performance and Management Review, 26(1), 5-25. Retrieved from http://www.jstor.org/discover/10.2307/3381295?uid=3738480\&uid=2129\&uid=2\&uid=70\&uid=4\&sid=21 104070582861

Bland, T., Bruk, B., Kim, D., \& Taylor Lee, K. (2010). Enhancing Public Sector Innovation: Examining the Network-Innovation Relationship. The Innovation Journal: The Public Sector Innovation Journal, 15(3), 1-18. Retrieved from http://www.innovation.cc/scholarly-style/bland_enhancing_public15v3a3.pdf

Borins, S. (2006). The Challenge of Innovating in Government. Washington: IBM Centre for the Business of Government. http://www.businessofgovernment.org/sites/default/files/BorinsInnovatingInGov.pdf

Bovaird, T., \& Loffer, E. (2009). Public Management and Governance. London: Routledge.

CCAF. (2010). Innovation Risk and Control. Ottawa: CCAF-FCVI Inc. Retrieved from https://www.ccaf-fcvi.com/index.php?option=com_content\&view=article\&id=542\&catid=89\&Itemid=99\& lang=en

European Union. (2013). European Public Sector Innovation Scoreboard 2013. A pilot exercise. Retrieved from http://ec.europa.eu/enterprise/policies/innovation/files/epsis-2013_en.pdf

Giedraityte, V., \& Raipa, A. (2012). Inovaciju igyvendinimo trukdziai siuolaikiniame viesajame valdyme. Viesoji politika ir administravimas, 11(2), 187-197. Retrieved from https://www3.mruni.eu/ojs/public-policy-and-administration/article/view/845/802

Glor, E. D. (2003). Innovation Traps: Risks and Challenges in Thinking About Innovation. The Innovation Journal: The Public Sector Innovation Journal, 8(3), 1-18. Retrieved from http://www.innovation.cc/scholarly-style/glor_innovation-traps.pdf

Hamson, N. (2004). Why Innovation Doesn't Work: And What To Do About It. The Innovation Journal: The Public Sector Innovation Journal, 9(1), 1-7. Retrieved from $\mathrm{http} / / / \mathrm{www}$.innovation.cc/discussion-papers/hamson-emp.pdf

Isaksen, S. G., \& Tidd, J. (2006). Meeting the Innovation Challenge: Leadership for Transformation and Growth. Chichester: John Wiley \& Sons, Ltd.

Kamensky, J. (2011). The Next New Thing in Performance Management. PA Times, 34(5), 6-14. Retrieved from $\mathrm{http} / / /$ connection.ebscohost.com/c/opinions/70696058/next-new-thing-performance-management

Kettl, D., \& Fesler, J. (2009). The Politics of Administrative Process. Washington D.C.: CO Press.

Merton, R. K. (1992). Bureaucratic Structure and Personality. In J. M. Shafritz, \& A. C. Hyde, Classics of Public Administration (p. 101-109). Belmont: The Dorsey Press.

Moore, M., \& Hartley, J. (2008). Innovations in Governance. Public Management Review, 10(1), 3-20. http://www.tandfonline.com/doi/abs/10.1080/14719030701763161\#.U_R4fWNWI40

Mulgan, G., \& Albury, D. (2003). Innovation in the Public Sector. London: Strategy Unit. 
Nelson, K. L., \& Svara, J. H. (2012). Form of Government Still Matters: Fostering Innovation in U.S. Municipal Governments. The American Review of Public Administration, 42(3), 257-281. http://dx.doi.org/10.1177/0275074011399898

Page, S. (2005). What's New about the New Public Management? Administrative Change in the Human $\begin{array}{lllll}\text { Services. } & \text { Public } & \text { 7dministration }\end{array}$ http://dx.doi.org/10.1111/j.1540-6210.2005.00500.x

Palidauskaite, J. (2008). Valstybes tarnautoju motyvavimas: lyginamasis aspektas. Viesoji politika ir administravimas, 25, 7-18. Retrieved from http://www.mruni.eu/upload/iblock/363/1_j.palidauskaite.pdf

Palidauskaite, J., \& Segaloviciene, I. (2008). Valstybes tarnautoju motyvacinis profilis Lietuvoje: empirinio tyrimo rezultatu analize. Organizaciju vadyba: sisteminiai tyrimai, 47, 73-90.

Perry, J. L., \& Buckwalter, N. D. (2010). The Public Service of the Future. Public Administration Review, 70(Supplement s1), 238-245. http://dx.doi.org/10.1111/j.1540-6210.2010.02283.x

Robbins, S. P. (2006). Organizacines elgsenos pagrindai. Kaunas: UAB "Poligrafija ir informatika".

Segarra-Blasco, A., Garcia-Quevedo, J., \& Teruel-Carrizosa, M. (2008). Barriers to Innovation and Public Policy in Catalonian. International Entrepreneurship and Management Journal, 4(4), 431-451. Retrieved from $\mathrm{http}: / /$ link.springer.com/article/10.1007/s11365-008-0086-z

Tan, B. S. (2004). The Consequences of Innovation. The Innovation Journal: The Public Sector Innovation Journal, 9(3), 1-43. Retrieved from http://www.innovation.cc/scholarly-style/tan-9-3.pdf

The Gallup Organization. (2011). Innobarometer 2010. Innovation in Public Administration. Analytical Report. Retrieved from http://ec.europa.eu/public_opinion/flash/fl_305_en.pdf

Vidaus, R. M. (2010). Savivaldybiu administraciju strukturu analize. Studija. Vidaus reikalu ministerija, Vilnius. Retrieved from http://vakokybe.vrm.lt/index.php?id=415

Vigoda, Gadot, E., Shoham, A., Schwabsky, N., \& Ruvio, A. (2008). Public Sector Innovation for Europe: a Multinational Eight - Country Exploration of Citizens' Perspectives. Public Administration, 86(2), 307-329. http://dx.doi.org/10.1111/j.1467-9299.2008.00731.x

Walker, R., Boyne, G., \& Brewer, G. (2010). Public Management and Performance. Cambridge: University Press.

\section{Copyrights}

Copyright for this article is retained by the author(s), with first publication rights granted to the journal.

This is an open-access article distributed under the terms and conditions of the Creative Commons Attribution license (http://creativecommons.org/licenses/by/3.0/). 